\title{
SILICON SPECIATION IN LIGHT PETROLEUM PRODUCTS USING GAS CHROMATOGRAPHY COUPLED TO ICP-MS/MS
}

Raquel Sánchez, ${ }^{\mathrm{a},{ }^{*}}$ Fabien Chainet,,${ }^{\mathrm{b},{ }^{*}}$ Vincent Souchon, ${ }^{\mathrm{b}}$ Sylvain Carbonneaux, ${ }^{\mathrm{b}}$ Charles-Philippe Lienemann, ${ }^{\text {b José-Luis Todolía }}$

10 Figure S1. GC-ICP-MS chromatograms D4 at $1 \mathrm{mg} \mathrm{kg}^{-1}$ in heptane at different flow rates of $\mathrm{H}_{2}$ in the ORC $0.5 \mathrm{ml} \mathrm{min}$

$11{ }^{1}$ (red); $1.0 \mathrm{ml} \mathrm{min}{ }^{-1}$ (yellow); $1.5 \mathrm{ml} \mathrm{min}^{-1}$ (blue); $2.0 \mathrm{ml} \mathrm{min}{ }^{-1}$ (green); $2.5 \mathrm{ml} \mathrm{min}^{-1}$ (orange); $3.0 \mathrm{ml} \mathrm{min}^{-1}$ (purple).

12 Carrier gas flow rate: $0.5 \mathrm{~L} \mathrm{~min}^{-1}$; optional gas flow rate: $0.15 \mathrm{~L} \mathrm{~min}^{-1}$.

13 Figure S2. Ratio of the slopes for each silicon compounds for heptane, FCC and SR gasoline compared to another in

14 heptane at the second day.

15 Figure S3. Temporal variation of the recovery for the QC samples. Carrier gas flow rate: $0.5 \mathrm{~L} \mathrm{~min}^{-1}$; optional gas flow

16 rate: $0.15 \mathrm{~L} \mathrm{~min}^{-1}, \mathrm{H}_{2}$ gas flow rate: $2.0 \mathrm{~mL} \mathrm{~min}^{-1}$.

17 Figure S4. GC-ICP-MS chromatograms of the coker naphtha $B$ and $C$ samples (IS: internal standard). Carrier gas flow 

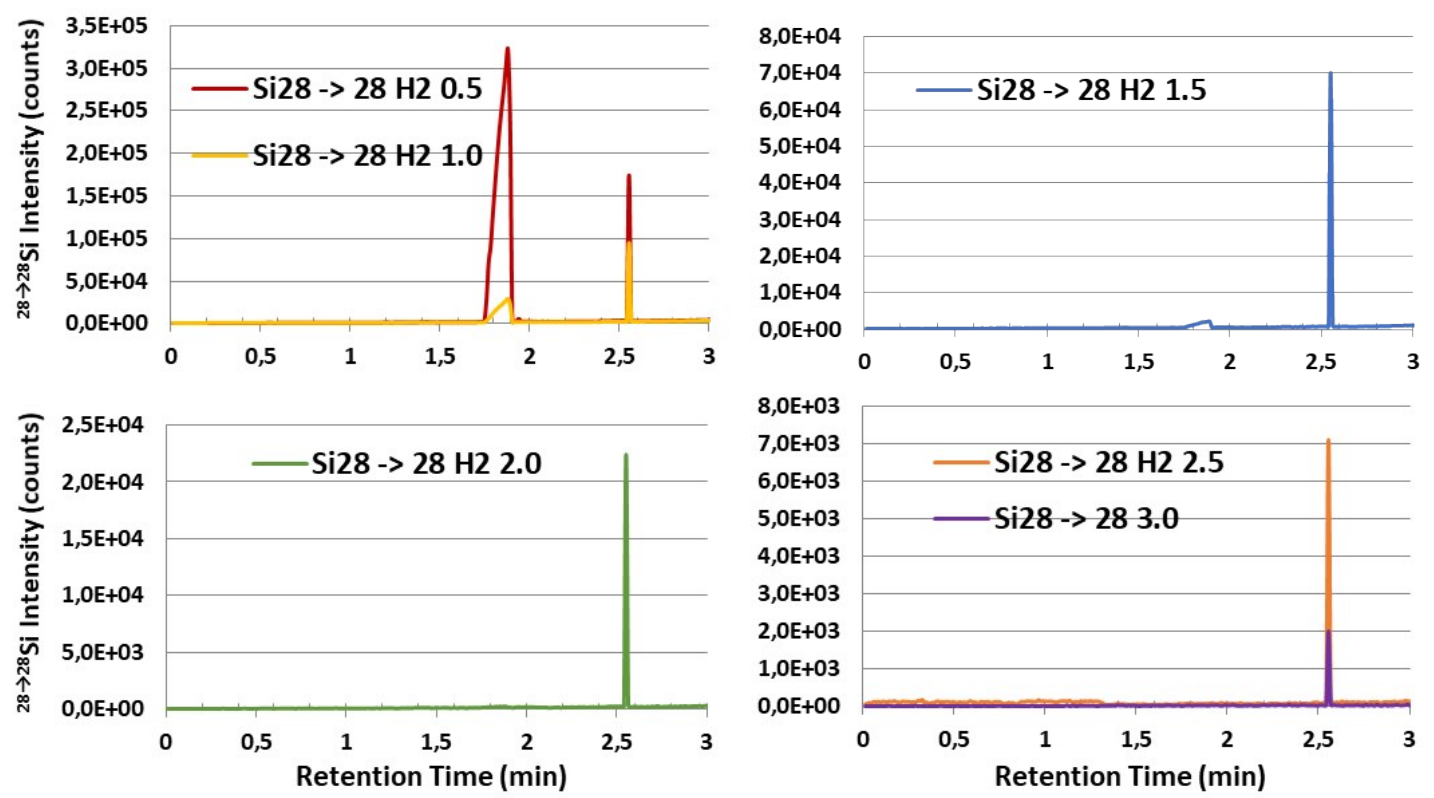

21 Figure S1. GC-ICP-MS chromatograms D4 at $1 \mathrm{mg} \mathrm{kg}^{-1}$ in heptane at different flow rates of $\mathrm{H}_{2}$ in the ORC $0.5 \mathrm{ml} \mathrm{min}^{-}$

$22{ }^{1}$ (red); $1.0 \mathrm{ml} \mathrm{min}{ }^{-1}$ (yellow); $1.5 \mathrm{ml} \mathrm{min}^{-1}$ (blue); $2.0 \mathrm{ml} \mathrm{min}{ }^{-1}$ (green); $2.5 \mathrm{ml} \mathrm{min}^{-1}$ (orange); $3.0 \mathrm{ml} \mathrm{min}^{-1}$ (purple).

23 Carrier gas flow rate: $0.5 \mathrm{~L} \mathrm{~min}^{-1}$; optional gas flow rate: $0.15 \mathrm{~L} \mathrm{~min}^{-1}$. 


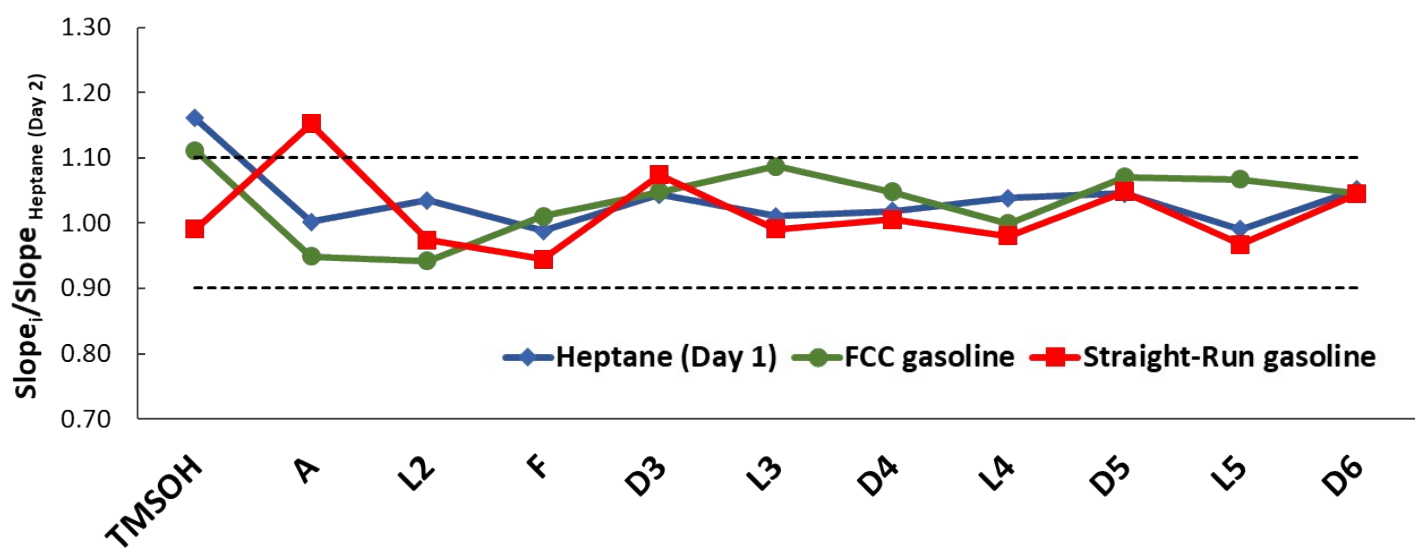

25 Figure S2. Ratio of the slopes for each silicon compound for heptane, FCC and SR gasoline compared to another in 26 heptane at the second day. 


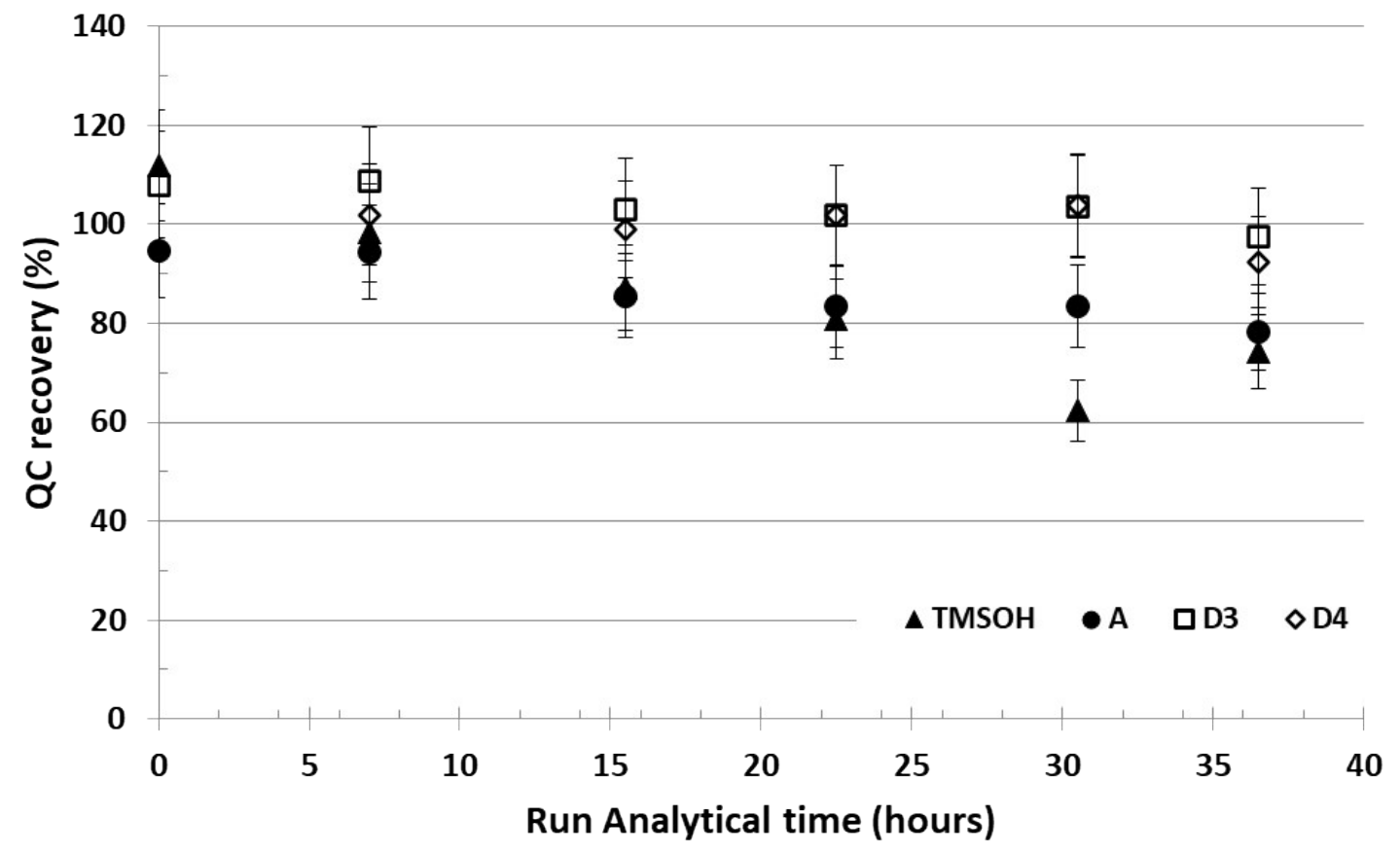

27 Figure S3. Temporal variation of the recovery for the QC samples. Carrier gas flow rate: $0.5 \mathrm{~L} \mathrm{~min}^{-1}$; optional gas flow 28 rate: $0.15 \mathrm{~L} \mathrm{~min}^{-1}, \mathrm{H}_{2}$ gas flow rate: $2.0 \mathrm{~mL} \mathrm{~min}^{-1}$. 


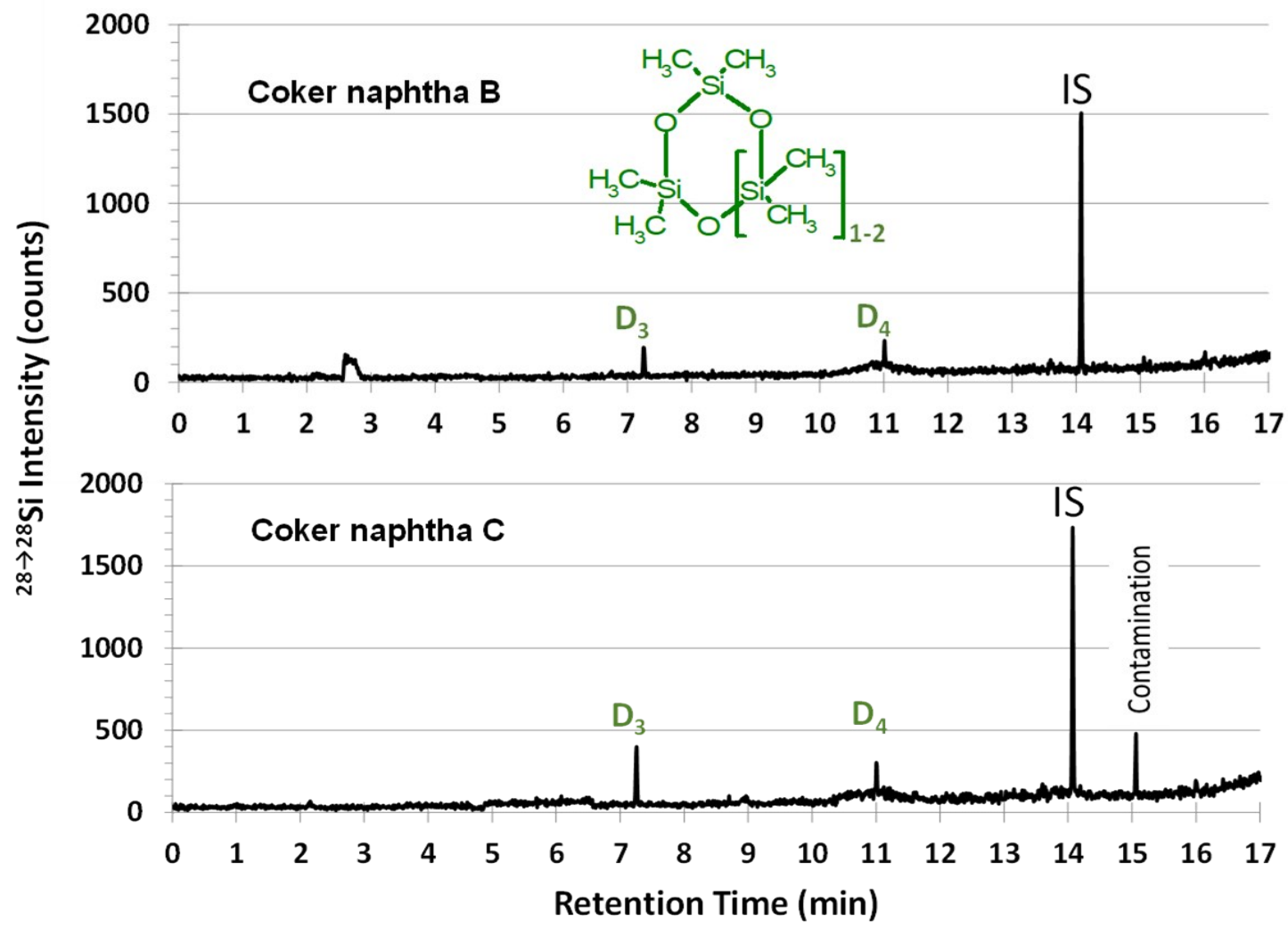

30 Figure S4. GC-ICP-MS chromatograms of the coker naphtha B and C samples (IS: internal standard). Carrier gas flow 31 rate: $0.5 \mathrm{~L} \mathrm{~min}^{-1}$; optional gas flow rate: $0.15 \mathrm{~L} \mathrm{~min}^{-1}, \mathrm{H}_{2}$ gas flow rate: $2.0 \mathrm{~mL} \mathrm{~min}^{-1}$. 